\title{
ARJEN EPÄKESKEISET TAVAT JA TOIMINNOT
}

EEVAJOKINEN: Aikuisten arki. Gaudeamus, Helsinki 2006. $261 s$.

Sosiologinen ja yhteiskuntapoliittinen tutkimus on viime vuosikymmeninä nostanut profiiliaan tarttumalla tutkimuksessaan yhä tiukemmin perinteiset sosiologiset kategoriat ja etenkin työn, kodin ja perheen kaltaiset perinteiset modernit instituutiot ohittaviin tutkimuskohteisiin. "Kulttuurin" tutkimus ei ole tietenkään mikään uusin virtaus yhteiskuntatieteen saralla, mutta ehkä juuri kulttuurisosiologian alueella on tapahtunut vähitellen koko tieteenalaan vaikuttavia merkittäviä muutoksia pois annetun struktuurin ylivallasta. Kulttuurisosiologia voidaankin ymmärtää ensisijaisesti toiminnan ja muutoksen tutkimukseksi, jossa pääpaino on elämän muodon, tavan ja tyylin rakentumisen tutkimuksessa.

Tällaisen yhteiskuntatieteen alueella tarkkanäköiseen ymmärrykseen on yltänyt erityisesti "mikrososiologinen", kvalitatiivisista menetelmistä ponnistava tutkimusote. Sen ytimessä on viimeisten vuosikymmenten aikana tapahtunut feministisen tutkimusotteen rakentuminen, sen radikaalin luonteen syvällinen ymmärtäminen ja samalla kokonaisen uudenlaisen yhteiskuntaontologian kehittyminen.

Tämä tarkoittaa, että kulttuurintutkijat eivät enää tutki "kulttuuria" vaan ensisijaisesti kiihkeässä käymistilassa elävää yhteiskuntaa. Näin päästään taas katselemaan ja kartoittamaan laajoja yhteiskunnallisia horisontteja, toisin sanoen maailmaa, jossa elämme, toisin silmin. Voi olla, että mikrososiologian ja naistutkimuksen eksodus on ohi, sillä juuri näiltä tutkimuksen aloilta kumpuaa jatkuvasti merkittäviä ja laaja-alaisesti tärkeitä yhteiskuntatieteellisiä tutkimuksia, jotka asettavat yhteiskuntaa koskevat ongelmat ja samalla niiden ratkaisun mahdollisuudet uudella tavalla.

En väitä, että Eeva Jokisen Aikuisten arki "edustaisi" tätä konstruoimaani kuvaa uudenlaisen sosiologisen tutkimuksen aallosta. Pikemminkin kuin ohittaen perinteisimmät sosiologisen tutkimuksen kohteet, se kulkee niitä kosketellen aivan niiden vierestä. Se toimii mielestäni ainutkertaisena ja rohkeana esimerkkinä tavasta hahmottaa ja tutkia monitasoista ja joka suuntaan "pakenevaa", mutta silti niin keskeistä - tai tarkemmin sanottuna epäkeskeistä - yhteiskunnallinen ilmiötä, arkea.

\section{ARKI ON PAKENEVA TUTKIMUSKOHDE}

Arki on todella hankala tutkimuskohde, koska se kuuluu kaikesta huolimatta sellaisten modernien yhteiskuntien "universaalikäsitteiden" joukkoon kuin 'työ' ja 'valtio' ja 'perhe'. Sinänsä voidaan kyllä löytää lukemattomia erilaisia ilmiötä, jotka kuvaavat näitä käsitteitä. Samaan aikaan nämä universaalit ovat kuitenkin jo tavalla tai toisella ratkaisevasti muuttumassa, vaikka niille on ilmeisen vaikeaa keksiä vaihtoehtoisia käsitteitä. Emmehän me voisi elää ilman valtiota, perhettä, työtä ja arkea - vai voisimmeko?

Joka tapauksessa voi kysyä, onko mahdollista löytää kokonaisia sosiaalisia ryhmiä, jotka voisivat sanoa elävänsä elämää vailla minkäänlaista arkea? Tällaisia henkilöitä tuntuu löytyvän, kuten rouva presidentti äärimmäisen julkisena 
olentona. Silti hänenkin elämästään on kirjoitettu useita artikkeleita, joissa kuvaillaan presidentin arkista puuhailua sekä arkeen välttämättömästi kuuluvaa toimintaa, kuten edustusta (joka taas sinällään ei varsinaisesti kuulu arkipäiväisen toiminnan perinteisesti ymmärrettyyn piiriin). Lisäksi on jo arkipäivää, että presidentti on nainen, vaikka itsenäisen Suomen arkikokemus ymmärtääkin presidentin vielä "melkein" miehenä. Arkea ei toisin sanoen voi työntää jonkin tietyn sosiaalisen alueen tai inhimillisen toiminnan ulkopuolelle, vaan arjella on taipumus hiipiä kuvaan myös juhlimis- ja bilettelykulttuuriin, siis äärimmäisen julkiseen toimintaan. Yleisti: ihmisten toiminnalla on taipumusta arkistua, ja tässä mielessä arkisuus voitaisiin määritellä juuri totunnaisuudeksi ja tapaisuudeksi, jota kuitenkin "häiritsee" tottumuksen ja tavan ei-niin-itsestään selvä luonne, toisin sanoen tapojen "pysymättömyys" ja "irrallisuus". Tämä jatkuva heiluriliike tuottaa totunnaisia rakenteita ja liittää tapaan itseensä jonkinlaisen eron ja toiston leikin, mutta samalla se tuo paradoksaalisesti tavan käsitteen välittömään yhteyteen muutoksen käsitteen.

Tällaisesta paradoksaalisesta määritelmästä myös Jokinen lähtee liikkeelle: "Arjen logiikkaan kuuluu 'vieraan' kesyttäminen 'kotoisaksi'. Kesyttäminen ei onnistu aina eikä ole ikinä aukotonta. Siksi arjen tarkastelu avaa oven sekä hyvinvointivaltion (ja muiden instituutioiden) rakenteisiin että inhimillisen toiminnan mahdollisuuksiin ja edellytyksiin." (Jokinen 2006, 12). Toisin sanoen Jokinen tutkii arkea sosio-ontologisesti, mutta hän ei lähde liik- keelle "olevasta" vaan "muutoksessa-olevasta" yhteiskunnallisesta rakentumisesta, jossa rakenteen ylläpitäminen on yhtä lailla toimintaa kuin tuon rakenteen muuttaminen. Rakenteen ylläpitämisen ja sen muuttamisen ymmärtäminen toiminnaksi ei kuitenkaan vielä ota kantaa jommankumman puolesta erityisesti tiedostettuna toimintana, sillä niin ylläpito kuin uudistaminenkin voivat olla sekä tietoista että tiedostamatonta toimintaa.

Teoreettisesti Jokinen ponnistaa Pierre Bourdieun sosiologiasta yhdistäen sen Foucault'n analyyseihin, Gilles Deleuzen ja Jussi Vähämäen näkemyksiin kontrolliyhteiskunnasta sekä erityisesti sellaisten naistutkijoiden kuin Teresa de Laurentiksen ja Judith Butlerin teorioihin. Keskeisiä korostuksia ovat performatiivisuuden ajatus ja toisintoimimisen tärkeys. Tällainen lähtökohta tutkimukselle on jo itsessään vaativa mutta lupaava, ja se implikoi väistämättä yhtäältä sitä, että arki ja arkinen toiminta avataan perin juurin uudella tavalla ja toisaalta sitä, että vastaus tai selvitys aikuisten arjesta ei ole yksiselitteinen ja helppo, vaikka Jokisen kirkas kirjoitustyyli ensisilmäyksellä näin antaakin ymmärtää.

Jokinen ei tartu kiinni tutkimuskohteeseensa ainoastaan kirjoittamalla. Aikuisten arki on laadullinen tutkimus, joka perustuu 39 suomalaisen miehen ja naisen haastatteluun. Haastateltavat, jotka olivat iältään 30-40-vuotiaita haastatteluja tehtäessä, kuuluvat siihen sukupolveen, joka on syntynyt ja kasvanut hyvinvointivaltion laajenemisen kultakaudella mutta aikuistunut ja pyrkinyt tai siirtynyt työelämään laman aikana. Tätä sukupolvea on nimitetty "laman säikäyttämäksi” sukupolveksi, joka ei luota mihinkään ja pelkää jatkuvasti pahinta. Jo sinällään tämän sukupolven haastattelu on tärkeä ja mielenkiintoinen projekti, koska kyseisen sukupolven edesottamukset näkyvät, kun osataan katsoa, yhteiskunnassamme yhä vahvemmin.

Kenties tästä säikähdyksestä johtuva keskiluokkaisuuden ja pikkuporvarillisuuden henkiinherääminen ja muodostuminen suorastaan ideologiaksi merkitsee suurta muutosta yhteiskunnallisessa asenneilmapiirissä. Yhdessä 1990-luvun päätöksentekijöiden sosiaalipoliittisten päätösten kanssa se on johtanut perhearvojen vahvistumiseen ja voimistanut uusfamilialistista politiikkaa, joka yrittää keinotekoisesti pitää hengissä ydinperheen, heteronormatiivisuuden sekä perheen ja työn erillään pitämisen perinteisiä malleja. Kiristyvillä työmarkkinoilla se merkitsee myös sitä, että omaa turvaa ja lutuista perheonnea ollaan valmiita puolustamaan keinolla millä hyvänsä ja että solidaarisuus työtovereita, työehtoja, -palkkoja ja -aikoja kohtaan saa usein väistyä. Jos "perhefasismin" käsitettä ei olisi vielä keksitty, se täytyisi keksiä nyt.

Tässä uudessa järjestyksessä on melkein itsestään selvää, että pehmoisiä ei enää tarvita, sillä miehiä paremmin koulutetut naiset hoitavat pienet lapset kotona, ilmeisesti siksi, että sen "paremmin osaavat." Monet tasa-arvon pitkäaikaiset prosessit tuntuvat horjuvan vakavasti kiristyneen työja perhepolitiikan paineessa, eikä tämä edes ehkä ole mikään "aksidenssi" vanhakantaisella filosofisella käsitteistöllä ilmaistuna. Naisten euro 
on kääntynyt laskuun 80 centin vaihtokurssistaan, ja perheideologian seurauksena yksinhuoltajuus on hälyttävän suuri köyhyysriski, jota ei ole pyritty korjaamaan millään tavalla, vaikka yksinhuoltajuus lisääntyykin jatkuvasti.

Jokisen ja hänen tutkimusassistenttinsa Leena Åkerbladin tutkimus ei kuitenkaan onneksi keskity ainoastaan tämän negatiivisen kehityskulun ympärille vaan aukaisee sen lisäksi moneen suuntaan liikkuvan ja vetävän arjen kentän. Jokisen tutkimuksen arki on aidosti heterogeeninen kuva arjesta. Se rakentuu monesta kerrostumasta, kentästä ja toimijasta. Arjen inhimillisiin toimijoihin eli haastateltaviin kuuluu ihmisiä, jotka elävät sinkkuina, parisuhteissa, ydinperheissä, sateenkaariperheissä ja yksinhuoltajaperheissä. Myöskään arjen kontekstit, ne tilat, joissa arjen liike tapahtuu, eivät jää ainoastaan kodin ja ihmisten "arkipäiväisinä" pitämien asioiden tasolle, vaan Jokinen tarkastelee oivaltavasti erilaisia tapahtumapaikkoja ja ympäristöjä.

Tämän lisäksi arjen tilojen ja inhimillisen "elävän arjen" ulkopuolelta arkea ohjaavana tai sitä haltuun ottavana järjestelmänä tutkitaan erityisen kiinnostavasti muun muassa "äititapaista televisiota" sekä uusien teknologioiden, erityisesti tietokoneen, roolia arjen rakentumisessa. Tämä ei tarkoita sitä, että esimerkiksi televisio tai internet nähtäisiin yksisilmäisesti arjelle "ulkoisina", päinvastoin. Kuitenkin juuri nämä mekaanisen ja orgaanisen sekä työn ja vapaa-ajan välimaastossa toimivat koneet tuntuvat muuttaneet arkea paljon enemmän kuin edellisen sukupolven koneet, kuten pesukone.
Se, että televisio on jo vanha vimpain, jolla on oma kulttuuri- ja käyttöhistoriansa, ei poista sen yhä kasvavaa ja muuttuvaa roolia. Ehkäpä digitelevision vaikutus tulee jopa muuttamaan television "äitimäisyyttä" uuteen suuntaan lapsen ja miehen mielihaluja ja toiveita passaavaksi piikaäidiksi, joka toteuttaa toiveet kyselemättä aina romantiikan nälästä tuhteihin pornokesteihin.

Kansallisvaltiollisen televisiokanavasysteemin hajotessa ja television kansaa kokemuksellisesti yhteen sitovan roolin murentuessa olisi kenties viimein yritettävä löytää jollain tapaa laajempia näkökulmia yhteiskunnassa toimivan ihmismoneuden toiminnan kontekstualisointiin ja ymmärtämiseen, erityisesti koskien ihmisten suhdetta uusiin teknologioihin. Tällaisia pohdintoja avaa Jokisen tutkimus, jossa asiaa käsittelevät erityisesti luvut kuusi "Tietokonearkea" ja seitsemän "Tuttu ja turvallinen televisio". Nämä "arjen ontologiaa" koskevat tutkimukselliset avaukset ovat äärimmäisen mielenkiintoisia, koska ne osoittavat kontrolliyhteiskunnan ${ }^{1}$ ja uudenlaisten toimintatilojen, kodin ja työn hybridin luomisen suuntaan ja saavat toivottavasti osakseen tavalla tai toisella jatkotutkimusta ja -analyysia.

Toisin sanottuna Jokinen osoittaa tutkimuksessaan, että arki pakenee jatkuvasti ja yhä uusiin suuntiin uusfamilialistisesta mallista huolimatta, vaikkakin usein tuon mallin ahtaudesta kärsien. Se liikkuu pois kodin ja perheen perinteisistä tiloista ja instituutioista ulos kaduille, työpaikoille ja virtuaalimaailmaan. Arki on pakeneva, epäkeskeinen ja tästä johtuen erityisen tärkeä yhteiskuntatieteellinen tutkimuskohde.

\section{ARJEN ALKU JA LOPPU}

Mutta eikö ongelmaksi tällaisen universaalin aiheen kanssa nousekin se, kuinka rajata arki, kuinka luoda sille alku ja loppu, mihin karsinoida tutkimusongelma ja kohde? Jokisen teos alkaa luvulla "Arjen paradoksit", joka kertoo jo paljon niin siitä tutkimusotteesta kuin tutkimuskohteestakin, johon itse tutkimus sukeltaa.

Tutkimuksen mallina ei ole kaava, jossa "alusta" kuljettaisiin pitkää ja vakaata keskitietä loppuun ja päätelmiin, jotka tiedettiin jo jokseenkin ennalta. Sen sijaan itse tutkimus päättyy "Arkipolitiikkaa" -lukuun, joka ikään kuin palaa takaisin ensimmäiseen lukuun: arki ei ole lähtökohtaisestikaan itsestään selvää, sillä arki on luonteeltaan paradoksaalista. Arjella ei ole alkua tai loppua, vaan se on enemmän tai vähemmän ympäripyöreää, sillä sen luonteeseen kuuluu kierto, joka rakentuu erosta ja toistosta, lähtemisestä ja paluusta.

Koska arki on luonteeltaan paradoksaalista, on syytä kyseenalaistaa kaikki ne itsestäänselvyydet, joiden varassa se lepää, niin "tavallisten ihmisten" mutu-tuntuma kuin tieteellinen "mä kyllä tiedän" -tuntuma, ja avata arki sen sijaan jatkuvasti uudelleen määrittyväksi kamppailun kentäksi, voimasuhteiden ja neuvottelujen alueeksi, jossa minkään ei lopulta tarvitse olla itsestään selvää, koska arki on luonteeltaan poliittista. Tai kuten Jokinen kirjoittaa: "Arkisuus on se kerrostuma, jossa puolihuolimattomat ja vakiintuneet tapaisuudet kytkeytyvät päälle. 
Merkitysten arkistuneisiin ketjuihin voi ja pitää puuttua, jos ne ovat julmia tai ne synnyttävät yhteiskunnallista eriarvoisuutta." (Jokinen 2006, 156.)

Sen lisäksi, että tämä lausuma on sellaista sanankäyttöä, jota yhteiskuntatieteilijältä kaivataankin varovaisten "olisikohan mahdollisesti näin" -raportointien sijaan, kertoo tämä jotain tärkeää elämänmuodostamme. Arki, kuten niin monet muutkin yhteisöelämäämme liittyvät itsestäänselvyydet, näyttäytyy meille aivan liian usein mekanismeina ja proseduureina, jotka "kytkeytyvät päälle" heti kun niiden kanssa ryhdytään toimimaan tai niiden kentälle astutaan. Mutta mihin onkaan hävinnyt luottamus henkilökohtaiseen kokemukseen ("arki tuntuu tällaisena ikävältä ja tylsältä") ja omaan arvostelukykyyn ("tämä juttu arjessa ei musta ole kyllä nyt ihan oikein") ja niistä kumpuavaan kykyyn muuttaa vallitsevaa mekanismia tai omaa toimintaa suhteessa tuohon "koneeseen"? Sosiaaliset "koneistot" ja "mekanismit" eivät ole luonteeltaan sellaisia, että ne toimisivat vain yhdellä ja ainoalla tavalla: päinvastoin, sosiaaliseen mekanismiin kuuluu se ihmeellinen piirre, että niitä kyetään muuttamaan, niiden toimintatapaa ja periaatetta voidaan varioida huolimatta siitä, että niiden funktio pysyy edelleen samana, jos näin halutaan.

Ja jos arjen funktioksi ymmärretään juuri "vieraan" muuttaminen "tutuksi" sekä totunnaisuuden ja tavanomaisen toiminnan - jopa rutinoitumisen - mukanaan tuoma elämän helppous, niin meidän tulisi uskaltaa rohkeasti käydä muuttamaan niitä arjen käytänteitä, jotka tekevät siitä ikävää ja aiheuttavat hyvin- kin syvällisiä ristiriitoja, sillä arjenhan tulisi olla elämää helpottavaa, ei hankaloittavaa toimintaa. Toisaalta juuri arjessa tapahtuvat muutokset, vaikka niillä olisikin "hyvä tarkoitus", voivat tuntua erittäin vaivalloisilta ja hankalilta ja siksi vastustettavilta.

Voidaankin sanoa, että arkipolitiikka pyrkii hallitusti muuttamaan arkea sellaiseksi, että se palvelee tarkoitustaan, mahdollistaa helppouden ja vapauden oikeudenmukaisesti, ei epäsymmetrisesti. Koska arki on epätyydyttävää, on kamppailtava sen muuttamisesta ja järjestämisestä tyydyttäväksi. Juuri siksi myös tavan käsite saa tekstissä seuraavanlaisen muotoilun: "Tapa on toimintaa, joka paitsi toistaa sitä, mitä on aina tehty, myös ennakoi tulevaisuutta. Tämä ennakoinnin ulottuvuus luo särön tottumukseen 'toisena luontona'. Tavat voivat muuttua, ja itse asiassa juuri tavat voivat sysätä muutoksen liikkeelle." (Jokinen 2005, 156.)

Kun arki rakentuu yhä vähemmän kronologisesti niin yksilöllisellä kuin yhteiskunnallisellakin tasolla (ei siis niin, että arkea olisi "kotona ennen töitä ja töiden jälkeen" vaan pikemmin siten, että yhteiskunnan prekarisoitumisen myötä on arkista olla "kotona töissä", kuten Jokinen Uuden työn sanakirjassa sivuilla 171-172 esittää) joutuu myös poliittisen "paikka" liikkeeseen. Se laajenee fragmenttiin ja instituutioon suljetusta muodostaan koko yhteiskuntaan, siis myös yksityisen alueelle. Arjen politiikassa aikaa hallitsevana tekniikkana ei ole siis kronologia (kuinka hallitsen aikafragmentteja ja järjestän ne peräkkäin sopivaksi tarinaksi, mitkä osat joudun syystä tai toisesta hylkäämään) vaan pikemminkin kairologia, kairoksen eli "nyt-hetken" oikea havainnointi, erilaisten toistensa päälle ja varaan rakentuvien, toisiinsa sekoittuvien aikaelementtien laajentaminen ja kaventaminen kulloinkin tarvittavan kokonaissommitelman aikaan saamiseksi ja tässä sekoituksessa tarvittavan oikean toimintatavan avaamiseksi. Se tunnustelee aikatiloja ja hahmottaa tapahtuman oikeaa muotoa (ja tämä on myös työelämän "kotitöistymisen" yksi olennainen piirre). Kairologia arjesta selviytymisen ja sen muuttamisen menetelmänä kertoo omalla tavallaan myös kotityön ja "taloudenhoidon" tai "huushollauksen" siirtymisestä jälleen yleisemmäksi yhteiskunnalliseksi malliksi, sillä esimerkiksi Jussi Vähämäen mukaan kairologia tarkoittaa nimenomaan ajan säästämistä ajan, tai jopa aikojen, tuntemisen perusteella (Vähämäki 2003, 45). Se siirtää siksi arjen pois yhden kansallisvaltiollisen ja "oikean arjen mallin" jäljittelystä kohti monipolvista ja rönsyilevää, intuitiivista tapaa hoitaa ja rakentaa arki. Kuten Jokinen mainitsee, tämä tarkoittaa usein niin kodin kuin työnkin intensivoitumista, etenkin kun ne sekoittuvat ajallisesti ja tilallisesti toisiinsa. Kyse ei ole siis mistään "vapautuksesta" vaan uudenlaisesta tavasta toimia.

Tämä jos mikä tarkoittaa arkisten tapojen muutosta, eikä suinkaan "tavanomaisempaan" suuntaan. "Tapa hoitaa arki" on muuttunut "tavoiksi hoidella arkia", ja tämän muotoilun jokainen sana kertoo todellisesta, ei vain kielellisestä muutoksesta. Siksi arjen muutokset kertovat myös välttämättä mahdollisuudesta 
poliittiseen muutokseen, joka tulee jatkuvasti kairoksen tavalla läsnä olevaksi toimintamahdollisuudeksi, toimintaavaruudeksi ilman annettuja rajoja tai toiminnan hetkeksi ilman ennalta päätettyä alkua ja loppua.

\section{SUKUPUOLIKYSYMYS} JA ARKINEN TYÖNJAKO

"'Vanhemmuus' on tasa-arvoretoriikan huipputuote: se viittaa molempien vanhempien merkitykseen. [...] Vanhemmuudesta puhuminen häivyttää sen toistaiseksi yhteiskunnassamme merkittävän seikan, että äidit ja isät tekevät eri asioita." (Jokinen 2005, 129.)

Yhteiskuntamme perhekeskeiseen liturgiaan kuuluu lausahdus, jonka mukaan "vanhemmuus on hukassa". Mitä tämä lausuma pitää sisällään, mihin se viittaa? Miksi se lausutaan? Mitä tapahtuu, jos vanhemmuus joutuu sellaiseen ihmeelliseen paikkaan kuin "hukka", paikkaan, joka itse asiassa viittaa ikiaikaiseen susivihaan ja metsään. Mieleen nousee väistämättä satu pikku kileistä: oliko kilien yksinhuoltajaäiti "huono äiti", kun hän lähti kaupungille ostoksille ja jätti lapset "oman onnensa nojaan"? Periikö hukka siis lapset, joiden vanhemmat tai "vanhemmuus" ovat "hukassa" välttämättömyydestä, kuten esimerkiksi tukiverkoston puuttumisesta ja liian vaativasta työelämästä johtuen? Mikä paikka tuo "hukka", jossa vanhemmuus piileskelee, oikein on? Onko se arkikielenkäytön mukaan paikka, joka on jossain mutta ei oikein kuitenkaan missään. Vai olisiko vanhemmuus pikemminkin hajallaan ja siirtynyt pois ydinperheen keskiöstä, kuten muukin arki, vai onko se todellakin hä- vinnyt johonkin tilapäisesti, jonnekin mistä se voidaan taas löytää sellaisena kuin "se aina ennenkin oli"? Ja mitä sitten tapahtuu, kun vanhemmuus löydetään? Tätä saivartelua voisi jatkaa vaikka kuinka laajasti, mutta olennaista Susi ja seitsemän pientä kiliä -tarinassa on se, että kaiken perii hukka, melkein. Kun isä ei ole suojelemassa perhettä, on koko perhe vaarassa joutua hukan perimäksi. Melkein. Varmaankin yhteiskunta tämän sadun mukaan hajoaa totaalisesti ydinperhemallin murtumisen jälkeen. Onneksi kilien äiti on kuitenkin päättäväinen ja päättää toimia toisin, lastaten suden mahan täyteen kiviä ja upottaen sen lopullisesti kaivoon. Sitten kukaan ei ole enää vaarassa joutua hukkaan. Toisin on kuitenkin yhteiskunnassamme, jossa tällä hukkapiilolla pelotellaan naisia pysymään parisuhteissa, hyvin ikävissäkin sellaisissa, oikein toden teolla. Ehkä olisi todella tehtävä jotain sen hyväksi, että tämä mielikuvituksessamme elävä pelote saataisiin pois päiviltä eikä kenenkään tarvitsisi ensisijaisesti pohtia sitä, kuinka seuraavasta päivästä selvitään hengissä.

Mutta millaisia vanhemmuuden malleja tai hierarkioita yhteiskunnassamme on rakentumassa? Suomessa yksi viidesosa lapsiperheistä on yksinhuoltajaperheitä, ja lukumäärä kasvaa jatkuvasti. Markkinoiden rakentamasta häähumusta ja "nyt me mennään naimisiin" -rallatuksesta huolimatta, tai ehkä juuri sen ansiosta, uusien avioliittojen keskimääräinen ikä on noin neljä vuotta. Avioliittoja mahtuu elämään ehkä useampia kuin aikaisemmin, hieman samaan tapaan kuin työuriakin eri aloilla. Suurin osa parisuhteiden "pätkätyöläisistä", yksinhuoltajista, on tietysti naisia ja kuin "sattumalta" juuri nämä perheet ovat erityisen suuressa riskissä ajautua köyhyysloukkuun. Nämä pätkätyöläiset tekevät ja hoitavat välttämättömät arkiset työt ilman sen kummempia sitoutumisia ja katteettomia avio/työsopimuksia. Työ tapahtuu yhteiskunnallisen työnjaon kaikkein heikoimmilla tai lähes olemattomilla työehdoilla, joista voi valittaa korkeintaan vertaisryhmälle (toiselle yksinhuoltajalle), sillä "ääneen" eli julkisesti näistä asioista ei juurikaan keskustella. Tehtävien ulkoistaminen vaatisi rahaa, ja sitä puolestaan ei yksinhuoltajille haluta antaa. Näin siis yksinhuoltajilla, kuten prekaarissa tietotyössäkin, työ jatkuu lakkaamatta, vain elanto tai "palkka" on pätkittäistä ja kangertelevaa.

Prekaarissa tietotyössä, jota jälleen kerran kuin "sattumalta" tekevät pääasiassa koulutetut naiset, heijastuu tulevan työn ja sen hallinnan yksi perustyyppi. Yhtä lailla yksinhuoltamisessa havaitaan perheisiin kohdistuvan vallan ja hallinnan uusi ilmiö. Jos uudessa työssä työsuhteesta tulee entistä enemmän työnantajan ja työntekijän keskinäinen neuvottelusuhde, josta muut osapuolet on suljettu ulos (niin yhteiskunta kuin työkaveritkin), niin Jokisen kirjan perusteella myös perheissä voidaan havaita saman tyyppinen muutos: vanhemman ja lapsen suhteesta on tulossa kaikkein kestävin suhde parisuhteiden muuttuessa aikakauden luonteen mukaan pätkäsuhteiksi. Juuri tästä syystä vanhemmuudesta puolestaan muodostuu varsinainen biopoliittisen hallinnan paikka. Hallinnan kohteena ovat 
tulevat työläiset, se mahdollisuusvarasto, joka juuri tällä hetkellä rakentuu lasten varttumisen myötä. Kapitalismi tähtää iskulauseidensa mukaan "seuraavan sukupolven" haasteisiin, ja edellytyksien noiden haasteiden ratkaisuille sanotaan muodostuvan kasvavassa nuorisossa. Siksi vanhemman ja lapsen suhde on aikaisempaa tärkeämpi yhteiskunnallinen, taloudellinen ja poliittinen suhde.

Vanhemmuus ei tietenkään ole "hukassa". Pikemminkin vanhemmuus on muuttunut käsitteeksi ja hypännyt onnistuneesti kontrolliyhteiskunnan metatasolle, jossa vanhemmuudesta on rakennettu biopoliittinen hallinnan väline, dispositiivi, jonka kautta perheiden elämisen tilaa säädellään. Vanhemmuus ulkoistuu kokemuksesta ja "tekemällä oppimisesta" joksikin omituiseksi suoritukseksi, jonka oikeat ohjeet ja mallit voidaan löytää ainoastaan kasvatusoppaista ja aikakauslehdistä. Vanhemmuudesta rakennetaan diskurssi, jolla tuotetaan jatkuvasti keskustelua niin "hyvästä" kuin "huonostakin" vanhemmuudesta, "äitiydestä" ja "isyydestä", joihin sitten Foucault'n kuvaileman pastoraalisen vallan ja sen tunnustusmenetelmien avulla tartutaan yhä hanakammin. Ehkä yksi tapa vastustaa vanhemmuusdiskurssia ja "vanhemmuuden" kautta toimivaa valtaa on pitää suunsa kiinni, kun kysytään, ja olla tunnustamatta mitään. Kysymykseen "millainen vanhempi olet" on parasta vastata Melvillen Bartlebyta mukaillen, että "mieluummin en ole vanhempi" kuin ryhtyä sen kummemmin reflektoimaan omaa vanhemmuuttaan. Juuri tämä vanhemmuuden reflektointi on biopoliittisen vallan tapa tart- tua kiinni alamaisiinsa. Valitettavasti yhä useammin kieltäytyminen keskustelusta tarkoittaa myös miinusmerkkiä vanhemman ja yhteiskunnan välisessä diskurssissa, vanhemman ja etenkin lapsen menetykseksi. Siksi ehkä parasta vastarintaa "kodin ja koulun" ja "päiväkodin ja kodin" keskusteluissa on sittenkin kertoa suoraan se, mitä tästä järjestelmästä ajattelee.

Nämä vallan uudet "hyväntahtoiset" ja kommunikatiiviset muodot kertovat siis muutoksesta yksityisen ja julkisen suhteessa ja instituutioiden uudesta innosta tunkeutua "keskustelemaan" ja "avaamaan näkökulmia" kaikkiin mahdollisiin paikkoihin, aikoihin ja tiloihin. Jokinen kuitenkin huomauttaa, että vanhemmuuden diskurssia voidaan muuttaa, koska diskurssit ovat nimenomaan kulttuurimaisemia, eivät luonnon maisemia. Mutta kuten Jokinen jatkaa, myös muutoksessa on syytä olla varovainen, sillä diskurssia "hyvällä" muuttamaan pyrkivät avaukset voivat päätyä lopulta aivan toisenlaisiin tuloksiin.

Ei "hukassa oleva vanhemmuus" silti tietenkään koske vain yksinhuoltajia, vaikka näissä perheissä muotoutuukin siis jotain hyvin keskeistä tulevasta yhteiskunnasta. Samaan aikaan uusfamilialistisessa perhepolitiikassa naisten "ura" ja elämä ovat itsestään selvä uhraus, kun perheeseen hankitaan lapsia. Menestyvän firman ("perheen") on pidettävä kiinni ydinosaamisalueistaan, ja muut työt voidaan perheen taloudesta joko ulkoistaa (piika tai palvelija) tai kaataa jo palkatun henkilökunnan (vaimon) niskaan. Yritysretoriikan mukaisesti vain huippuyritykset - siis miehet - tuottavat rahaa yhteisöön, ja vain sitä kautta voidaan rakentaa hyvinvointia. Siis: hyvinvointi maksaa, ja naisten tulisi tämän ajattelutavan mukaan olla kiitollisia siitä, että miehet kantavat heille rahaa kotiin, jotta naiset voivat hoitaa lapsia, tulevia tuotantoyksiköitä, parhaissa mahdollisissa puitteissa. Jälleen nainen, joka tässäkin tapauksessa on lapsen ensisijainen vanhempi, kohtaa juuri "vanhemmuuteensa" kohdistuvat paineet ja vallan: kotiäitiys onkin missio, se ei ole välivaihe tai pakollinen rupeama, josta pitäisi jotenkin selvitä hengissä. Kasvatusoppaat kertovat, kuinka kaikki minkä lapsi oppii ensimmäisten vuosien aikana, vaikuttaa dramaattisesti hänen tulevaan kehitykseensä. Siksi rahaa tekeville miehille on annettava varoitus: varmistakaa, että lastenne äideiltä ei ole vanhemmuus hukassa, sillä muutoin lapsestanne ei kenties kasvakaan viatonta ja itsenäistä yksilöä.

Nämä tasot kuvaavat nykyisen prekaarin työn ja työkyvyn (workfare) yhteiskunnan työhierarkioiden ääripäitä yksinhuoltajien tehdessä Mcdonalds-tyyppistä matalapalkkaduunia turvatakseen jälkeläisen olemassaolon ja varttumisen aikuiseksi (tuottaen prekaaria työvoimaa, sillä "työttömyys kasautuu", kuten tilastoihin tuijottavat yhteiskuntatieteilijät osaavat kertoa) ja "kotiäitien" tehdessä huipputuottavaa "aivotyötä" tuottaen huippuyksilöitä tuleviin huippuyrityksiin - ja näiden väliin rakentuu se aikaisemmmin "keskiluokkana" tunnettu kasti, jonka piirissä elämä ja vanhemmuus ovat kenties ennen kaikkea sekaisin, mutta eivät niinkään hukassa. Tämä "ketjutyöläisten" luokka hoitaa perhettään vaihtelevin tavoin 
ottaen mallia sieltä ja täältä sekä kohdaten mitä kummallisimpia lasten hoitamista ja vanhemmuuden rakentamista koskevia vaatimuksia. Täällä käydään joka tapauksessa kenties armottominta kamppailua sukupuolikysymyksestä ja hoivan laadun ja määrän rakenteesta. Yritysjohtaja-"mies" ei tiskaa tai hoida lapsia muulloin kuin silloin kun hän haluaa leikkiä pehmoisää laatuaikanaan, eikä yksinhuoltajaperheissä "isää" luonnollisestikaan näy.

Ketjutyöläisperheissä sen sijaan tiskivuorofeminismille on otollinen maaperä ja juuri täällä mahdollisuudet muutokseen ja toisin toimimiseen ovat kenties lopulta kaikkein suurimmat, ellemme ota huomioon laajoja yhteiskuntapoliittisia muutoksia, joihin palaan lopussa. Itse asiassa ketjutyöluokan työelämän prekarisaatio voi jopa edesauttaa toisin toimimisen kehitystä, sillä nykyisin nainen voi olla se ensisijainen breadwinner miehen hoidellessa kotia (tyytyväisenä tai tyytymättömänä, sillä ei juurikaan ole väliä). Toisin sanoen, kiitos työelämän rakenteiden murroksen, on muutos pois naisille itsestään selvästä kakkosvuorosta kotona mahdollinen. Tätä edesauttaa lopulta myös töiden hiipiminen kotiin ja kodin ja työn sekoittuminen. Yhteiskunnan ja työelämän prekarisaation tendenssi antaa siis naisille kaikki muutoksen mahdollisuudet. Nyt on kyse vain toiminnasta ja toisin toimimisesta sekä arkipäivän vastarinnasta, jossa talouden toinen aikuisosapuoli pakotetaan ottamaan huomioon myös toisen tarpeet ja toiveet. Prekarisaation tilanteessa ei ole mitään itsestään selvää mallia, jonka mukaan tulisi toimia. Kaikki on siis mahdollista, mutta mikään ei riipu yksilön ratkaisuista, vaan yhteistyön laadusta ja määrästä.

Mistä tässä kaikessa valtapelissä on sitten kysymys? Ei mistään sen kummemmasta kuin sukupuolikysymyksestä. Vaikka yhteiskuntamme on elänyt sen kannalta todella historiallisia aikoja, joiden merkitystä filosofi ja naistutkija Kirsti Määttänen on usein korostanut, näyttää tämä tilanne työmarkkinoiden muuttuessa ja työtahdin koventuessa jälleen olevan palaamassa alkutekijöihinsä. Kyse on siitä, että myös miehet hoivaavat ja hoitavat vauvoja - isompien lasten lisäksi. Kyse on siitä, että myytti naisten "hoivavietistä" ja hoivaamisen äititapaisuudesta voisi viimeinkin murtua. Perinteisten dualismien rakenteistaman mallin kokonaisvaltainen kyseenalaistaminen liittyy tiiviisti ihmisten arkitoimintaan ja saa mielestäni toiveikkaan ilmaisun juuri siellä. Sellaiset dikotomiat kuin mies-nainen, kotityö ja yksityinen-julkinen, jotka pitävät yllä heteroseksuaalista matriisia, on mahdollista purkaa toimimalla toisin, performoimalla "ristiin" ja myös "unohtamalla" sen, kuinka asiat "tulee" tehdä, kuinka koti tulee hoitaa ja kuinka arki tulee järjestää. Arjen muisti rakentuu ja säilyy sukupolvien saatossa, ja se luo yhteiskuntaamme sen sisäisen jänteen, joka kannattelee luutuneita käsityksiä.

Heteroseksuaalisen matriisin purkaminen tarkoittaa myös heterotapaisuuden purkamista ja heteroajattelun purkamista. Tämä ei kuitenkaan tarkoita sitä, että tavoitteena olisi siirtyä homogeeniseen rakenteeseen, päinvastoin. Heteroseksuaalinen matriisi tuottaa ja ylläpitää homogeenista väestöä ja "kansaa". Heteromatriisin kyseenalaistava toisin toimiminen sen sijaan tarkoittaa itse eron, myös sukupuolieron, affirmoimista. Se tarkoittaa erojen vapauttamista annetusta järjestelmästä ja erojen liikkumista vapaasti yhteiskunnallisella kentällä. Se tarkoittaa sisäisesti ristiriitaisen moneuden toimintaa, jossa tärkeäksi tekijäksi nousee se, mitä tehdään, ei niinkään se, mitä sanotaan tehtävän. Toisaalta tärkeäksi seikaksi nousee tietysti myös se, $m i$ ten asioista puhutaan ja kuinka asioita käsitellään. Olennaista on, mistä lähdetään liikkeelle: patriarkaalisen yhteiskunnan heteronormatiivisesta "näinhän se on" -rakenteesta vai siitä, mitä ihmisten elämässä todella tapahtuu, niistä lukemattomista käytännöistä, ratkaisuista ja elämänmuodoista, jotka elävät yhteiskunnallisten itsestäänselvyyksien ja "tavallisten arkisten asioiden" alapuolella. Vain kontrolloiva valta haluaa "tavallista" arkea, kun ihmiset sen sijaan haluavat elää $t a$ vallaan arkea. Tähän arkeen kuuluu välttämättä mahdollisuus ennakoida tulevaa sellaisella tavalla, että se mahdollistaa vapaan tilan ja liikkeen arjessa. Arjen ennaltaarvattavuus ja "se tavallinen arki" on sen sijaan muotti, josta on kamppailtava irti.

Arki on ilmiselvästi politiikan paikka, jonka yhtenä työvälineenä voisi toimia esimerkiksi perustulo tai vastaava yhteiskuntapoliittinen uudistus: se mahdollistaisi elämän ilman heteroseksuaalista matriisia, ilman naisen taloudellista riippuvuutta miehestä. Se mahdollistaisi valinnan kodin ja työn välillä kenelle tahansa eikä ainoastaan pakottaisi tähän valintaan naisia, jotka ottavat nykypäivänä 
kohtuuttoman riskin suhteessa työelämään tuottaessaan yhteiskunnan uusintajia. Ja ehkä perustulo tai muu arjen rakennetta uudelleen avaava yhteiskuntapoliittinen ratkaisu toisi arkeen myös lisää aikaa, joutilaisuutta ja mahdollisuutta kieltäytyä lisäarvoa tuottavasta työstä, jota tehdään yhä useammin kotona, käyttöarvokkaan "kotityön" hyväksi. Tulevaisuuden yhteiskuntapoliittisten ratkaisujen pitäisi tavoitella tilannetta, jossa myös kotona on mahdollista kieltäytyä töistä niin koti-, kasvatus- kuin ansiotöistäkin. Aikuisten arki osoittaa uuden kriittisen yhteiskuntatutkimuksen suuntaan ja se avaa yhteiskunnan valtamekanismit sillä kentällä, jossa valta kohtaa myös vastarintaa. Ehkä Foucault'ta uudelleen muotoillen voidaankin sanoa, että Aikuisten arjessa "tämä epäkeskeinen ja hajakeskitetty ihmiskunta on monimutkaisten valtasuhteiden seuraus ja väline ja siinä ovat ruumiit ja voimat joutuneet moninaisen vapaudenriiston ja tämän strategian osina olevien teorioiden kohteiksi. Tässä ihmiskunnassa kantautuu nyt kuuluviin taistelun kumu."

\section{Mikko Jakonen}

\section{$v$ i i t e}

1. Kontrolliyhteiskunnan käsitteestä katso mm. artikkelit "Jälkikirjoitus kontrolliyhteiskuntiin" ja "Kontrolli ja muutos" (Deleuze 2005). Kontrolliyhteiskunnan käsitteellä ei tule ymmärtää yksioikoisesti katkosta suhteessa esimerkiksi Michel Foucault'n kuvailemiin "kuriyhteiskuntiin" (jotka hahmottuvat erityisesti vankiloissa rakennetun työmo- raalin ja homo oeconomicuksen rakentamisen kuvausten kautta (ks. erit. Foucault 2000, $167-$ 182) ja toisaalta itsekurin ja sitä tuottavan panopticon mallin (ks. erit. 338-350) kuvauksen kautta Tarkkailla ja rankaista -teoksessa), vaan kontrollien aikakausi tulee ymmärtää ensiksikin uutena vallan muotona, joka ohittaa instituutioihin ensisijaisesti sitoutuneen vallan, mutta ei karkota näitä instituutiota pois vallan toimeenpanevalta kentältä, vaan pikemminkin intensivoi instituutioiden, kuten kodin, koulun, armeijan ja yliopiston, toimintaa. Foucault'n sanoin: "Nykyään ongelmana on pikemminkin noiden normaalistamisvälineiden suuri kasvu sekä niiden mukanaan tuoma vallan vaikutusten laajuus, joka on syntynyt siten, että on muodostettu uusia oppialoja" (Foucault 200, 421). Instituutiot ja niiden "normaalistamisvälineet" joutuvat yhä suurempien tehokkuusvaatimusten ja "kasvun" alaiseksi, mikä pakottaa ne ensiksikin liikkumaan ja "hajauttamaan" toimintaansa ympäristöönsä eli muiden instituutioiden alueelle. "Äitijohtaminen" on yritysmaailman viimeisintä slangia (Kirsi Piha). Sota on levittynyt terrorismin muodossa jokapäiväiseen elämään, ja koko elämästä on tullut yksi suuri työprosessi ja maailmasta yksi suuri työpaikka. Kontrolleissa ei siis niinkään kontrolloida itse fyysistä liikettä, aktuaalisia toimia, vaan toiminnan mahdollisuuksia, niiden "esirakentumista” tai niiden eräänlaista metafysiikkaa, toisin sanoen ilmiöiden mahdollisuusehtoja. Siksi myös uusfamilialistinen perhepolitiikka keskittyy kotiin ja kodin arvoihin: ne nähdään yhteiskunnallisen ja työelämän taustana, sinä ihmeellisenä "yksityisen" alueella piileskelevänä pyhänä ytimenä, josta kaikki yhteiskunnalliset ja erityisesti yksilön käyttäytymisessä havaittavat piirteet virtaavat kuten Plotinoksen emanaatio- opissa. Uusfamilialis- missa koti on metafyysinen paikka, se on yhteiskunnan havaitsematon rakenne. Ruokatottumukset ja siitä mahdollisesti aiheutuva lihavuus, alkoholinkäyttö ja siitä mahdollisesti aiheutuva työhaluttomuus ovat kaikki "kotoa opittuja" tapoja. Tällöin ihmisen toiminasta tehdään kotona (joka ymmärretään joksikin ehdollistavaksi ärsykkeiden kautta toimivaksi tietokoneohjelmaksi tai pikemminkin tietokoneen, tietotyöläisen ohjelmoijaksi) "opitun" säännön yksioikoista, mutta tiedostamatonta seuraamista. Tällöin siis toisin sanoen ohitetaan itse toimijan ratio, hänen järkensä ja valintansa, ja siirretään vaatimus ration ja järjen asettamisesta "toiselle tasolle" eli kotiin, joka ei kuitenkaan itse asiassa sijaitse missään fyysisessä tilassa, vaan on nyt nimenomaan sosiaalinen suhde valtarakenteineen määrättyjen ihmisten välillä. Tämä tarkoittaa suurta mullistusta modernin tai kuriyhteiskunnan toiminnassa, sillä nyt kontrolli ja tarkkailu pyritään (entistä vahvemmin) ulottamaan juuri kotiin eivätkä yhteiskunnan muut instituutiot voi "yhteistyöhalukkuudestaan" huolimatta tehdä muuta kuin "korjata kotona aiheutettuja vahinkoja". Kontrollit eivät vie siis meiltä instituutiota, mutta ne vievät meiltä mahdollisuuden vaikuttaa ja kyseenalaistaa instituutioiden toimintaa, sillä jokainen instituutio on "ulkoinen" markkina-arvon kaksoismerkityksessä. Kun instituutiosta tulee tavara, se menettää kaiken itsekontrollin ja kurin, ja juuri tätä tarkoittaa astuminen kontrollien yhteiskuntaan: instituutioiden toimintaa kontrolloivat nyt ensisijaisesti markkinat, joilla toiminnan esitetään olevan "tavanomaista" ja "tavallista" - markkinoiden luonnonlakien eli metafysiikan sanelemaa. Tämä käsitys markkinoiden ohjautumisesta jonkin pysyvän säännön tai "ohjelman" mukaan ei tietenkään pidä paikkaansa (esim. raaka-aineiden 
hinnan mukaan ks. Marazzi 2006.) vaan markkinoiden toiminta on organisaatiossaan ja tapahtumia determinoivassa olemuksessaan hyvin vahvasti poliittis-taloudellista. Jokisen sanoin: "Kontrollien valta on sidoksissa arkisuuteen ehkä enemmän kuin 'vanhanaikainen' instituutioille jaettu kurissa pitämisen valta. Kontrollien valta synnyttää yhteiskunnallista eriarvoisuutta nimenomaan "tavallisen julmuudella". Käytännössä tämä tarkoittaa ainakin sitä, että kannattaa olla varovainen esittäessään sellaisia lausuntoja kuin 'ihmiset tarvitsevat lisää tavallista arkea'. (Jokinen 2005, 159.) Sama koskee vaatimuksia "tavallisesta elämästä" ja "tavallisesta politiikasta".

\section{K I R J A L L I S U U S}

Deleuze, Gilles 2005: Haastatteluja. Suomentaneet Anna Helle, Vappu Helmisaari, Janne Porttikivi ja Jussi Vähämäki. Tutkijaliitto, Paradeigma-sarja, Helsinki.

Foucault, Michel 2000: Tarkkailla ja rangaista. Suomentanut Eevi Nivanka. Otava, Helsinki.

Jokinen, Eeva 2005: Aikuisten arki. Gaudeamus, Helsinki.

Jokinen, Eeva 2006: "Lasten hoitaminen", teoksessa Jakonen, Peltokoski \& Virtanen (toim.): Uuden työn sanakirja. Tutkijaliitto, Polemos-sarja, Helsinki.

Marazzi, Christian 2006: Pääoma ja kieli. Suomentaneet Riitta Kyllönen ja Taina Rajanti. Tutkijaliitto, Polemos-sarja, Helsinki.

Vähämäki, Jussi 2003: Kuhnurien kerho. Vanhan työn paheista uuden hyveiksi. Tutkijaliitto, Paradeigma-sarja, Helsinki. 